\title{
Bacteriophage T4
}

National Cancer Institute

\section{Source}

National Cancer Institute. Bacteriophage T4. NCI Thesaurus. Code C14302.

A double-stranded DNA virus that infects bacteria such as E. coli. 